\title{
O LEGADO DE PAULO FREIRE NOS ESTADOS UNIDOS DA AMERICA: ENTREVISTA COM IRA SHOR
}

Lucas Corcoran

https://orcid.org/oooo-ooo1-5622-8344

Ira Shor

\section{Introduction}

Ira Shor is one of the first academics to translate conceptually the critical pedagogy of Paulo Freire to a North American context. However, as will be made clear in the interview, the context in which Shor first developed his critical pedagogy was, and remains, very different then Freire's context in Brazil. Instead of educating illiterate rural folk in Brazil, Shor has worked primarily with students in New York City's public university system--the City University of New York (CUNY)--who come from some of the poorest neighborhoods of the city. Frequently, these students are immigrants or children of immigrants for whom English is not their first language. And the English that they do speak is formed by the local dialects and idioms found throughout the five boroughs of New York City. In high school, these students have become accustomed to an authoritative education. While other students in the city, who live in more affluent neighborhoods, with better public schools or whose parents can afford to pay for private schools, often have a generally pleasant experience with teachers who show interest in their development, the students whom Shor generally teachers at the College of Staten Island have had an educational experience full of rules, imperatives, orders, and threats of sanction placed 
upon them by authoritative education. Insead of being a role model, or even a friend, the teachers of these students more often than not play the role of educational cop: they are in the classroom to catch their linguistic errors "in the act" and punish them with a complex system of grading that is difficult to comprehend. Because of this pedagogical tendency, lots of students, by the time they arrive at CUNY already incorporated a defense strategy against the authoritarian classroom: it's better if the teacher doesn't know my name. That way I can pass the class and "survive."

In the first year of studies in the majority of universities in the States, students have to take a "writing" course. "Writing" is put in quotation marks here, since what precisely constitutes the subject matter of this course differs highly, depending on the local institutional setting of each university. How subject matter differs from university to university often shows the socio-economic division in the States. In private universities, this type of course often centers on rhetorical invention and compositional creativity. On the other hand, in public universities, the course tends to center on the rote learning of "grammatical" rules, since it is generally assumed that students from the working class lack the "basic" linguistic skills needed to write in a more critical and dialogic way. Or, in worst case scenarios, it is assumed that working-class students speak a "broken" idiom, totally inadequate for participation in academic life. Hence, the first job of a writing instructor in a public university is to "fix" the language of these students, so that it fits within the norms of academic discourse.

These "writing" courses (which are often called "basic writing" courses) are housed in English departments in U.S. universities. Usually it is the last course that literature professors want to teach, and when the department forces them to do so, they teach it begrudgingly. When CUNY began its open-admissions policy in 1969, there was a large need for professors to teach such courses. Shor was hired in this moment at the College of Staten Island. It is hard to translate what "Staten Island" means to someone not from New York. It's the borough that New Yorkers most often make fun of. The subway doesn't go there; you have to take ferry. For the majority of New Yorkers, Staten Island is off of the map. To Teach a basic writing course in a working-class university in Staten Island is the worstcase scenario for many literature professors. One could not be further from illustrious Manhattan, and its private and elite universities.

In this environment Shor began to development his dialogic method of teaching. In his critical practice, Shor outright rejects the belief that the linguistic skills of working-class students are insufficient for critical thinking. In his first book, Critical Teaching and Everyday Life (1980), Shor describes a series of examples of what he calls "problem-posing pedagogy." This pedagogical approach of Shore is rooted in the everyday language and experience 
of students. Through questions as simple as, "Why is the teacher's desk larger than the students' desks?", Shor aims to teach students "habits of mind" that generate critical and reflexive inquiry into the world. For Shor--and it would seem for Freire as well--education is always an existential problem. The themes of education ared derived from experience, so that teachers and students can jointly interpret experience and later return to live in the world in a more authentic way.

In the beginnings of the 21st century, within the an era of unrestrained growth of neoliberalism, Shor's pedagogy provides a crucial tool for educators who want to go beyond the repetition of official data the transmission of "skills" that only have an educational value within the marketplace of the global gig economy. If education is to be a process and not only a product, then it is imperative that that educators continue exploring the critical pedagogies of the 2oth Century, so that they can confront the current commodification of education, a process which benefits few sectors of society and undermines the rest. In this vein, we hope that this interview begins new conversations regarding critical pedagogy and re-establishes new connections between critical educators in North America and Latin America.

Lucas Corcoran, Mexico City, August, 16, 2018

\section{Interview}

1. Your practical-theoretical framework is critical pedagogy. How would you define the influence that Freirean theory, along with his body of work, has had on your approach to teaching and scholarship?

Paulo Freire had great influence on my critical practice in the classroom and in the books I published on critical pedagogy. Reading him in the 1970s and then working with him in the 1980 s and 1990s, contributed to my development as a teacher and as an advocate for social justice. Freire helped me understand how education is a subsector of society dominated by the "power now in power," as he frequently called the status quo. As an educator, I gained a deeper grasp of the theory and the practice in how to make oppositional pedagogy how to build with students a democratizing classroom.

Freire's legendary method for literacy was based in problem-posing dialogue around themes derived from the everyday lives of the students. This was the method I was testing for student-centered democratic teaching here in North America. Freire wrote in Pedagogy of the Oppressed that the first problem in education was to overcome "the student-teacher contradiction." Traditional education was built on an authority gap and a linguistic conflict which alienated teachers and students from each other. Freire, 
on the other hand, insisted that students must be cognitive subjects in the learning process, and not merely passive objects receiving official knowledge. In addition, students had to participate in forming the curriculum, articulating the educational goals and critiquing classroom activities. This means that as the teacher, I had to avoid talking at and talking over students. Teacher-talk as a professional habit silences students. Instead, I had to initiate the most student expression possible from the very first day of class while saying as little as was needed to make this happen. My key activity is inviting student utterances and writing by posing meaningful problems which inspired their response. I had to develop student-centered inquiries in a dialogic method of successively more demanding activities of reading, writing, debating, and thinking. Freire's insistence on critical dialogue around generative words and themes from the lives of the students clarified for me how to become this kind of educator. It answered what I consider the central questions of curriculum: "Where does subject matter come from and what do we do with it?"

2. What were the challenges that you faced in translating Freirean ideas from his Brazilian context to your context in the United States in general and New York City in particular? How did you have to change conceptually Freire's work so that it could be used in your local setting?

Paulo Freire developed the generative theme method of problem-posing for illiterate peasants and working-class adults in Brazil, in the 1950s. At that time, the Northeast of Brazil was the poorest part of the nation with a high rate of illiteracy. As it happened, those years were also a time of rising opposition. Mass movements from the bottom up were gaining momentum and consolidating to challenge the vastly unequal status quo. These mass movements gave Paulo's education work a larger political context while his literacy circles fed back into the growing momentum for democratic change.

Pedagogically, Paulo worked in what is called "nonformal education," which means the literacy program is structured by professional educators but is not institutional, organized but not bureaucratic, not legally compulsory, not based in students paying tuition--but rather a kind of voluntary popular education in community settings. My situation has been altogether different. For the last 50 years, I have taught writing courses to workingclass college students, recent graduates of high school and young adults in the workforce, here in the Northeast urban part of the US. My critical teaching has been part of "formal education" not "informal education," because my classes are institutional and bureaucratic, organized by and offered through a state-regulated college--not popular education based in voluntary community programs; attending my classes means paying tuition; entry is through 
formal application as part of a bureaucratic admissions process; the college and my course have many rules and regulations already in place, formulated far from our classroom by various authorities; I report attendance and issue letter grades A-F at midterm and endterm, formally filing these results with the college administration; I must also track those students attending college as part of a welfare program for the poor. Bureaucratically regulated, the college formally appointed me as an officer of the institution and gave me a title : Professor Shor. I did not nominate myself for a community-based program, as is typical in a non-formal popular education process. For the tuition-paying students, college is the next level of their long formal education after thousands of hours already spent in the lower grades, referred to as "Kindergarten to $12^{\text {th }}$ grade," or "k-12" for short. In thirteen prior years of formal schooling, the students have been repeatedly practicing traditional learning through pre-packaged materials. Paulo Freire famously named this standardized model of formal education as "the banking method" of instruction. These students have had very little exposure to participatory inquiry or democratic learning or critical study of self-insociety. Though the students I teach are working-class like Freire's original students, they are not impoverished but are often employed as well as "post-literate," working-class members of an affluent first-world nation. As high-school graduates, they already know how to read and write. Even though their literate skills are uneven and often weak despite 12 years of English studies, they are still "post-literate" while Freire's original students in Brazil were "pre-literate." I would add that the students in my classes are "postliterate" but "pre-critical" and the designation "pre-critical" could also pertain to Freire's adult students 60 years ago in Brazil. Because my students are post-literate, I have an advantage insofar as I can use printed materials as prompts for problem-posing and I can ask them to undertake writing from the first day of class. Thus, I begin at what Freire called the "post-literacy" phase of critical pedagogy while he began at the "pre-literacy" phase.

3. You have said that prior to meeting Freire you were already developing your own critical and dialogic pedagogy through teaching workingclass students in Staten Island, NYC. What were the similarities between your work, already in development, and the work of Freire when you first read Freire's books? In other words, what in the Freirean theory helped you deepen your own thinking and your approach to teaching when you first encountered it? How have you continued to interpret and reinterpret Freire throughout your career?

When I began teaching at Staten Island Community College in 1971, I had a PhD in literature. I began publishing 
literary scholarship in academic journals. However, my doctorate in literature was of little help in becoming a teacher of critical literacy for working-class students. "Literature" dominates the enormous field of English education in the U.S., and literary scholars dominate the huge profession of English educators, yet the main problem of such mass education is not teaching fine literature but rather teaching critical writing and reading. A vast army of overworked and underpaid writing instructors are the majority of English instructors in higher education. Facing the colonial-style control of literacy by literature, I switched my own professional practice from belletristic matters to the teaching of writing, reading, and thinking. When I started teaching, there were no doctoral programs for composition and rhetoric, only PhDs in literature. Now, graduate and doctoral programs for compositionists are available but writing instruction is still the subordinate part of English studies.

The genres of literature-fiction, poetry, drama-were alien texts in a remote language to most of the workingclass students in my college classes. Literature study was being done to them for their own good, to expose them to finer discourses. This distance of English study from the language and experiences of everyday life developed passive students waiting to be told what things mean. This traditional teaching did not engage them in critical inquiry, which means looking deeply into any text or issue to understand its history, social causes, power relations, and relations to the personal contexts of the students themselves. Freire insisted that the act of reading should be "reading world when we read the word" by which he meant that the reading of texts should connect to the students' personal conditions. All in all, then, my first encounters with teaching at this working-class college taught me that I had to become a teacher of critical literacy which invited students into a deep encounter with non-fiction materials which posed problems about their world.

Subject matters had to be legible and meaningful to them, if I wanted to include them in a participatory learning process. They had to make knowledge and question knowledge instead of passively receiving knowledge from the teacher. I intuited that student experience and student language use had to bethe foundations of lessons and syllabi. The subject matters had to be tangible while my teacher's voice had to be disciplined and strategic. As one student wrote to me on the first day of class, "Don't kill us with your voice." Students are used to loud teacher voices talking over them as the dominant sound of classrooms, what Freire saw as generating in students "narration sickness." Loud, continual teacher-talk is the alienating sound-track of students' educational lives. A critical counter-pedagogy had to be based in colloquial, conversational speech about the conditions and experiences of their lives. This is what I observed in the early years of my teaching. As I 
experimented then, a colleague told me about an educator who wrote about such pedagogical problems, Paulo Freire. So, I started reading Freire around 1973 and found in his work theory and practice about critical teaching, discourse and subject matter, and the power relations of school in society.

4. You began teaching in NYC during the 70 s. When, in general, people were a lot more ready to resist and protest. How have your students changed during the last 40 or so years? How have you had to re-interpret Freire in order to adjust your teaching to the changes you see in your students? On the other hand, during this period we have also witnessed a shocking rise in neoliberal ideology. What are some of the changes that you can recognize in your students during this surge of neoliberalism and how have you reacted to it?

When I arrived at Staten Island Community College in 1971, the stage of American society was filled with mass movements and militant protests. Mass opposition was large against the war in Vietnam, against poverty, racism, women's oppression, homophobia, and against the toxic pollution of the planet. It was a wonderful time to be young and militant in demanding democratic change. Protest movements from the bottom up were on the offensive, creating an opening to the left which put the authorities on the defensive. This democratic era in school and society opened the door for many young teachers and students to experiment in their classrooms.

I worked in an English Department with a progressive majority which supported my experiments. While the overall tone of American society was then dominated by protest culture, the locale where I taught college writing, in Staten Island, was historically the most conservative and racist of the five boroughs in New York City. Staten Island as a territory was not liberal; it was an enclave of reactionary forces, with many police officers and firefighters living there, as well as a concentration of organized crime figures and a vocal contingent of anti-abortion foes. However, as happens in many conservative areas where colleges are located, the college campus itself was a liberal enclave. The young people in Staten Island in my writing classes back then came of age in an insurgent era so deep that it even reached their communities and appealed to their youth consciousness. Many dressed like hippies. A critical mass of them had caught the rebellious spirit of the age---sex, drugs, and rock and roll, as well as marching to protest the Vietnam War. This political contradiction of the locale with the campus helped me become an oppositional educator when the national opening to the left outweighed local control by the right. Five years later, by 1976, after relentless assaults by resurgent authorities who imposed drastic budget cuts at the dawn of neoliberalism, the campus and 
the entire university system were shut down during final exams because of a bogus financial emergency. Hundreds of young faculty who had been leading the protests of that time were fired. My own job was barely saved while most of the radical colleagues with whom I worked were dismissed; as a result, the faculty shifted suddenly and decisively to the right. The City University of New York (CUNY), tuitionfree for 129 years since its founding in 1847, then imposed tuition for the first time as well as repressive entry exams in writing, reading, and math to reduce enrollments. Almost 100,000 students were driven out of CUNY that time. This neoliberal assault continues to this day, 40 years later. Decade by decade, as the conditions for teaching, learning, and living got worse for my working-class students, they became more stressed, more anxious, more vulnerable, less able to devote time and attention and income to their education, less open to critical experiments. Of course, such changing conditions required changes in my pedagogy to cope with the changed political conditions.

5. What do you see as your continuing work at CUNY - a public university system that has been able to maintain a semblance of socialist programs meanwhile the neoliberalization of American universities, in general, continues unabated?

CUNY has been a major target of neoliberalism since the battles of the 1970s. Back then, CUNY had an egalitarian and democratic breakthrough: In 1969, protesting students on several campuses forced the authorities to implement an Open Admissions Policy that was more radical than planned. The Board of Higher Education (BHE) then operating CUNY had planned to admit all graduates of the city's public high schools by 1975, but their policy would continue protecting the elite four senior colleges-City, Hunter, Queens, and Brooklyn-closing them to lowerlevel applicants, because these campuses did not want to accept students who were often poor, non-white young people with the least invested in their development. The student movement at that time forced the BHE to open CUNY early in 1970, and--most egalitarian of all--to admit all students to all campuses regardless of the high school they attended. This was an historic opening of higher education to groups who had been excluded. The reluctant authorities were forced into this position by the mass movements of that time; yet, as would become clear, they refused to adequately fund the mass influx of new students, which doubled the number of first-year students enrolling. The under-funding of this experiment damaged its potential because of the inadequate resources, however the democratic spirit of that time still inspired young teachers and students to push ahead with innovations in favor of the new non-elite learners. The battles continued year after year until finally the BHE simply locked the gates of all 18 campuses in June 1976 to force a crisis that led 
to mass firings of faculty, imposition of tuition, and the mandating of repressive entry exams in reading, writing, and math, which turned Open Admissions into a vast underfunded empire of remediation staffed by overworked and underpaid part-time instructors ("adjuncts"). In my English Department when I arrived in 1971, there were 50 full-time faculty and perhaps 20 adjuncts who taught in the evening. Now, we have about 35 full-time faculty and 100 adjuncts. What labor economists call "the casualization of the workforce" was pioneered in higher education before spreading throughout the national job market. Clearly, public goods like public education have been starved in this age of neoliberalism. We need a consolidated movement of teachers who join forces with CUNY's students and other labor unions in this city to reverse this destructive policy.

\section{In more personal terms: How did you come to meet Freire? And what was it like working with him? Do you have any anecdotes that stand out in your memory?}

Paulo Freire read my first book, Critical Teaching and Everyday Life (1980), and wrote me a letter thanking me "for the beautiful words" as he put it. A colleague at the University of Michigan had handed Freire a copy of my book when he passed through there, telling Paulo that some North Americans are very interested in his work. I acknowledged in that book my debt to Freire but did not think to send a copy to Brazil. One day, I opened my mailbox in New York, saw a blue aerogramme with exotic postage on it, and the name Paulo Freire handwritten in the corner. I was astounded and delighted to hear from him. Some months later, Paulo called me from Stanford University where he was in residence and asked me to come join him there for the seminar. I couldn't travel just then, so Paulo told me he would be in Amherst, Massachusetts in February 1984 and hoped I would come there. I agreed and met him in Amherst in the winter of 1984, making three separate trips there to spend time with him. We met at a pizza restaurant where he was eating dinner with students; he rose to greet me as I approached the table and insisted I sit down next to him. His warmth and friendliness were overwhelming, very generous, unaffected, approachable, kind and welcoming, with a warm feeling in his voice. He looked in your eyes when you spoke with him and would often put a congenial arm on your shoulder. He spoke with a Portuguese accent and was unashamed to ask for help in finding the English word he was looking for. (The longer we worked together, the more I learned how to speak an English he found easiest to understand.) One night in Amherst, he called me onstage to join him at a large public forum, where he introduced me to the crowd as "his son," an honor that overwhelmed me. (Paulo liked to share the stage with others. He saw his role as a means to elevate others and to draw as many people into dialogue about 
what needs to be done.) After a few visits then to Amherst, I proposed we do a book together on the questions teachers in North America were asking me about critical pedagogy and how to do it. Paulo instantly agreed, "Let's begin tomorrow!," which we did. For the next two years, I traveled wherever he was in the North to work together on the book, which we finished and published in 1986, $A$ Pedagogy for Liberation, the first "talking book" Paulo Freire did with a collaborator, now in its $11^{\text {th }}$ printing in the States, published also in Great Britain, and in translation in Brazil, Greece, Israel and China.

7. You and Freire were not only colleagues, but good friends. What did you learn through this friendship about yourself as a person and as an intellectual? What are some sides of Freire that you got to know that might not come across to his readers in his writing?

Paulo Freire loved the food, the music, the humor, and the colloquial Portuguese spoken in his native Brazil, whose culture and life he sorely missed during his sixteen years of forced exile after the coup of 1964. Hungry as a child when his family fell into poverty in the 1930s, Paulo as I knew him in the 1980 s enjoyed conviviality over good food and wine ("Dao" and "Beaujolais" were his favorites vintages but he also liked the Brazilian "cachaza" which is distilled from sugar cane and is locally distinctive depending on the region of Brazil where it is made, he explained to me when I visited him in São Paulo in 1987). When it came to food, Paulo liked the national bean stew of Brazil, fejoado, along with liver and arugula, which he wanted to eat daily when he visited me in New York. Food even drove Paulo to philosophy. Soon after we met in Amherst in 1984, we went to the African-American Student Center on campus where a special lunch was prepared to honor Freire's visit. At the Center, I saw a marvelous buffett of African-American food. Hungry, I filled two dinner plates when my turn at the buffett came. I took my two heaping plates to a table where Paulo was seated. When he noticed the double mounds of food in front of me, he said with cheerful curiosity, "You are eating two lunches." I responded, "Yes, I love food." Paulo's face then lit up and he declared that my appetite had philosophic value, "That is good to love food! I do not trust people who do not like food. To love food is to love life! Food is biophilic!" I was pleased beyond telling and felt that my appetite had received an eminent endorsement. This was the first of many good meals I would enjoy with Paulo Freire.

8. You have said that the process of publishing Pedagogy of Liberation, your book co-authored with Freire, was difficult, on the one hand, and amusing, on the other. Could you describe the genesis of this work and explain about what you 


\section{and Freire had to do so that the book was finally published? Ultimately, what was the reception that it had in the United States?}

In Question 6 above, I mentioned the genesis of $A$ Pedagogy for Liberation which I first proposed to Freire while in Amherst in the Winter of 1984. When he said to me "Let's begin tomorrow!", I went back to my motel room in Amherst and spent much of that night outlining a book. The next morning, at breakfast, Paulo read my proposal for a dialogue book based in a series of key questions North American teachers had been asking me as I traveled the U.S. giving talks and workshops. We went over the questions, decided that one major question would be the prompt for each chapter of our dialogue, and the order of questions. Of course, we lived on different continents just before the internet revolution made long-distance collaboration much easier. I had an early word processor from Epson which today would be considered slow and primitive; Paulo had no computer at all then; in fact, he wrote his texts long-hand while his first wife Elza hilariously berated him, "Paulo buy a computer!" Paulo also marveled at this technology, how it enhanced writing, and made us young scholars more productive in his opinion, but he was then in his 60 s and not about to reinvent his composing habits. So, after meeting at Michigan in May, 1984, we co-authored an annotated table of contents outlining each chapter based on a seminal question raised by teachers I had met.

Paulo then told me he would be in residence in Vancouver, Canada, at the University of British Columbia for July, 1984, so we planned to meet there to tape our spoken dialogues on the questions we agreed on. I flew to Vancouver from New York in July with a colleague from the CUNY, an art educator professor, Herb Perr, who generously agreed to offer technical assistance in the many hours of taping ahead. At Vancouver, Paulo was leading an adult education seminar of 60 students every morning from 8am-12 noon, which I joined daily, in a classroom so crowded that I had to sit on a windowsill. I credit those many hours in seminar with Paulo as crucial to my own development as a critical educator because I listened day after day to how he framed answers and issues about the theory and practice of critical pedagogy, and the politics of education in school and society. After each long and intense session, we had lunch and then Paulo was busy with interviews for radio, newspapers, and television. He and I would rendez-vous at his campus apartment each afternoon around $4 \mathrm{pm}$ and work until 8pm. My colleague Professor Perr handled the tapes, the recording machine, the microphones, and a backup micro-cassette recorder; we asked a bilingual colleague at the University of British Columbia, Professor Ya-Ya Andrade, to sit in for Portuguese translation because Paulo sometimes preferred to express himself in Portuguese for a sentence, a paragraph, or a page- 
length utterance, which Professor Andrade immediately translated into spoken English aloud as I took handwritten notes; then, I would rephrase from my notes her literal English translation into different formulations of academic, educational, and colloquial American English, explaining the choices and nuances of each English version to Paulo to see which he preferred, which then became part of the taping as he spoke the translated section in English into the recorder. We worked like this for eight days straight. Each night around 8pm we went with Paulo's first wife Elza, my colleague Professor Perr, and sometimes a colleague or students from the University of British Columbia, to a Portuguese/Brazilian restaurant in town for a lot of good food, good wine, many stories and laughing. At midnight, we all went home and started again the next day at $8 \mathrm{am}$.

I took all the hours of tapes home and rented that fall a Dictaphone machine with a forward and reverse foot pedal and earphones to listen to the dialogues sentence by sentence, typing out a transcript on my Epson word processor, and storing each chapter on a disk. This took several months. By February, 1985, Paulo was back in residence for a month at the University of Massachusetts at Amherst, where I rejoined him with several printed copies of the transcript in hand, which we then read over line by line for several days making edits, corrections, and additions. I then took the edited transcript back to New York, and prepared the next draft, which I brought again to Massachusetts in July where Paulo was in residence at Boston College. We then reviewed this new draft, made corrections, and taped some additional segments we agreed were needed at various points. I took home this edited manuscript, re-typed it into a new draft, and returned to Amherst in February 1986 for the final monthly residence Paulo had at the University of Massachusetts, where we edited it again. Paulo came to New York later that spring for a week of sessions at Columbia University with the legendary founder of the Highlander Education Center in Tennessee, Myles Horton, and we confirmed the final draft, about two years after we began.

That spring, with a final draft nearly done, I approached various publishers in New York, and was rejected by all of them, who did not see the value of what Paulo called "a talking book." I even took it to a very clever New York agent with a progressive reputation, and she too said she could not sell or make money from such a book. We were then approached by Jim Bergin whose small press Bergin-Garvey was looking to develop an education line. He instantly wanted the manuscript which was printed in 1986, and afterwards has gone through perhaps twelve printings, was published in the UK, and translated for editions in Brazil, Israel, Greece, and China.

9. How would you describe the reception of Freirean pedagogy in the United States? What 
relevance do you see it having now? Has it fallen out of favor or increased its standing in the academic world?

Books on Paulo Freire have kept appearing since his unfortunate passing in 1997. Scholarly interest in Freire thus remains very high. Also, teachers continue adapting Freire to a variety of classrooms in diverse educational settings. Paulo Freire still excites attention and respect from progressive activists and critical educators who seek his theory and practice for their work. Of course, it was Paulo himself who insisted that he must be re-invented, not copied. He is famous for saying, "The only way to copy me is not to copy me." He was very clear that critical teaching is a form of "situated politics" by which he meant that the theory must be shaped into practices adapted for the specific situation where it is being tested. Those of us questioning the status quo in the name of social justice share a general orientation to school and society-that is, an orientation towards building social justice, democracy, equality, ecology, and peace in a cruel, unjust, and hostile world. While we share general values compatible with Freire's orientations, the specifics of implementing them in any setting are determined by the particulars of where we are, by the concrete conditions of our local times, by the specific assets and obstacles in each place, shaped by immediate power relations. With the $50^{\text {th }}$ anniversary of Pedagogy of the Oppressed having been celebrated in various conferences, the large and enthusiastic crowds attending indicate that Freire continues to be a luminary whose ideas are still meaningful.

10. How would you evaluate the educational situation in the United States in today's world and where does a critical perspective fit into it?

Neoliberalism emerged in the 1970 s in the U.S. and has been gaining ground and dominating all sectors of society. There has been a vast transfer of public wealth to private hands as all public goods---parks, schools, colleges, health care, housing, etc.-are being privatized into revenue streams for the very rich. The triumph of neoliberalism over the last 40 years which means the nullification of democratic rights and the decline of standards of living, is the big story of this age.

At the same time, power relations are not one-sided, not a monolith of neoliberal victories. In fact, politics in school and society in the United States have been moving left and right at the same time over the last four decades. The neoliberal ascent is certainly the dominant factor here and globally, with right-wing populism emerging worldwide, not just in the U.S. with Trump's victory. The politics of left opposition also has a story to tell in these dismal decades. The vigorous mass movements of the 1960 s/70s were confronted by reactionary counter-attacks from the top down. The protest culture of that earlier time 
is well-known for confronting racism, sexism, homophobia, corporate dominance, environmental degradation, and authoritarian schooling. These progressive movements forever changed the political culture of North American society, which is a far more liberal culture than it was 60 years ago. They pushed egalitarian changes in law, policy, mass media, fashion, music, as well as everyday habits and language use.

A counter-revolution from the right took shape with the election of Richard Nixon in 1968, whose campaign first mobilized retrograde whites and males with its appeal to the "moral majority." A key call-to-arms for this counterattack is a document known as "the Powell Memorandum," published by influential Virginia politician Lewis Powell at the request of the conservative U.S. Chamber of Commerce. This document, circulated on August, 23, 1971 by soon-tobe-Supreme-Court-Justice Powell, declared alarmingly that the nation was being overwhelmed by anti-democratic, lawless protestors who had to be stopped. Powell identified mass movements on and off campus as the threat. He chided corporate and government authorities for being too weak in the face of protests. To strengthen and direct these forces of reaction, Powell included a comprehensive agenda for authorities on and off campus, in and out of government, as well as those in charge of mass media and industry, to silence the out-of-control protesters. The measures he outlined amounted to a call-to-arms, reminding authorities at the top of society of the immense power and tools still in their hands but not being used. These tools were then put in play. In the next two decades, Powell's memorandum became a blueprint for what I call "the conservative restoration in school and society." This restoration of traditional authority against the democratic gains of the mass movements collapsed the liberal wing of the Democratic Party, which then drifted to the right as a common agent of neoliberalism with the Republicans, leading to a conservative Republican Party takeover of government at all levels, opening the door to Donald Trump's presidency, the most right-wing Administration of all.

At the same time, opposition forces have also emerged, including movements for Black Lives Matter against decades of police killings of young black men, \#metoo and TimesUp against the sexual violation of women, Youth Against Gun Violence following a series of horrendous school shootings, activism against Global Warming, etc. At this moment, American society is badly polarized right vs. left as the provocative vulgar President Trump agitates his base and his adversaries alike. It is not possible to predict which way this political tension will move in the coming years. Anxiety, disgust, dismay, and anticipation are high here.

11. How familiar are you with the current reception, the relevance, and controversy that 
the figure of Paulo Freire generates in Brazil, Argentina, and throughout South America? We believe that your opinion and testimony are very important in the current context.

About this, I only know of recent efforts by the right in Brazil to remove the honorary designation of Paulo Freire as "educator to the nation." The successful removal of Pres. Dilma Rousseff and the arrest of former Pres. Lula DaSilva has put the Workers' Party on the defensive, encouraging more right-wing actions there.

Interviewed: Dr. Ira Shor

Interviewer: Dr. Lucas (CUNY), Dr. Jorge Alejandro Santos (UBA)

Recebido em: 05/05/2019

Aprovado em: 21/11/2019

Publicado em: 20/12/2019 